\title{
DEVELOPMENT EFFORTS OF OIL COMPANIES AS PERCEIVED BY RURAL HOUSEHOLDS IN SELECTED OIL PRODUCING COMMUNITIES OF RIVERS , NIGERIA STATE.
}

\section{MATTHEW UKPONGSON AND DONATUS ONU}

\section{ABSTRACT}

A total of 120 respondents participated in the study to determine the perceptions of rural households toward oil companies' efforts to reach the hosts (rural dwellers) in 40 randomly selected oil-producing communities of Rivers State. Findings indicated that a lot of efforts have been geared by oil companies to reach their hosts (rural communities) however, $50 \%$ of the respondents agreed that such efforts are inadequate and ill-distributed to meet the expectations of the people. About $90.8 \%$ of the respondents disagreed that the host communities are highly satisfied with companies' efforts (projects and services) to them. Based on these findings, recommendations were made.

\section{Key words}

Oil producing communities; oil exploration/production; company's development efforts; 


\section{INTRODUCTION}

One of the most nagging problems facing the under-developed countries like Nigeria is how to improve the quality of life in the rural communities (especially the oil producing Niger Delta Communities); and also to integrate the rural dwellers into the main stream of development process to enable them lend their support and participate fully in development projects for sustainable existence. Our rural areas have been described as endangered and largely neglected as well as characterized as suffering from various disabilities in varying degrees of intensity. Such disabilities include remoteness, inaccessibility, backwash effects of development, poverty, drabness, ignorance and attendant conservation, emigration, disease, malnutrition and low productivity (Igbozurike, 1977; Adefolalu, 1977). Development generally and rural development in particular, attempt to remedy these conditions.

Rural development has in recent times become a prime focus in Nigeria's development efforts because majority of Nigerians live in the rural areas where oil exploration and production with oil related devastation, degradation and economic deprivations take place daily over four decades today. Rural development is the series of efforts directed at the transformation of the rural areas. It results in an increase in agricultural productivity. For rural development to have its real meaning, it is necessary that the interest of the resource-poor people is protected; there is need to protect and preserve their resources (land/soil, water, crops and mainly animals). Rural people in Rivers State are mainly farmers and fishermen with little or no other occupations, but are faced daily with environmental degradations. Not much impact may be created by any development strategy/agency, if it fails to protect and preserve the rural beneficiaries (Ukpongson, 1996). 
The ambit of rural development is very wide. It includes the generation of new employment, provision of tarred roads, potable water, electricity, more equitable access to arable lands, equitable distribution of income, widespread improvement in health, nutrition and housing, maintenance of law and order. It involves creating wider opportunities for individuals to realize their potentials through education and sharing in the discussions and actions which affect their lives (Nwakasi,1991). He further added that the provision of infrastructure is a major component of rural development. This is because, the absence of productive base is traceable to the non-existence of infrastructure and this is often thought to be responsible for the lack of sustained development in the under-developed countries hence rural poverty.

This lack of sustained development and hence rural-poverty of our producing communities, has over the years, been aggravated by oil exploration activities. While it is obvious that the oil industry has made immense contributions to the economy, it is true that there has been corresponding increase in the degree of problems associated with oil exploration experienced by the rural dwellers (lbe and Umesiobi, 1988; Loffa, 1990; Tolofari, 1982; Oroh, 1991; OMPADEC 1994). Over the forty years of oil exploration in the rural communities of Nigeria, the process has left a trail of devastation in terms of ecological destruction, environmental pollution and economic, social and other forms of human deprivations stemming primarily from planelessness and neglect by oil companies (OMPADEC,1994). Furthermore, these problems degenerated and accumulated with consequences, which had threatened social order and security of oil operations and major parties .

According to Ukpongson and Onu (1998), there are hardly anything to show as symptoms of development in the rural oil producing 
areas. How can any one think of what goes in there as development whereas, the threat and risk of oil pollution, thermal heat, gas flares, decreasing crop/fish yields over the years etc are continual and increasing daily? For development to be sustainable and meaningful they added, it must protect, preserve and conserve the lives and resources of the rural inhabitants. This is because, sustainable development implies in part that, available and present resources must be utilized by present generations in such a way/manner that maximum benefits are derived therefrom without jeopardizing the chances of future generations from benefiting from similar resources. However, the present trend in oil prospecting in Nigeria does not appear o obey this rule up to expectation, instead, the oil areas are left to wallow in abject state of poverty and neglect.

Still, OMPADEC (!994) adds that the communities lack the most basic infrastructural facilities (potable water, electricity, communications, roads to link them with the outside world for commercial and social interactions. Their farming and fishing grounds have been devastated and marine life in many areas destroyed, their lives are threatened daily by noise pollution and other health hazards. They drink from the very rivers and rivulets which have been polluted by petroleum extracts making development difficult.

The sum total of all development objectives is to make life more meaningful and allow the people feel the impact of the "new dawn" of development. This must be sustainable and capable of enabling the people attain their full human potentials. However, the search for sustainable rural development may hardly be successful in rural oil communities where environmental devastations are on the increase on 
a daily basis while rural poverty stare the people in their faces since oil exploration appears to be a never-ending process!

Dudley (1969), argues that a country's development can only be real when questions on what has been happening to poverty, unemployment, inequality and the habitat itself have been fully answered. From what are on the ground, the oil companies are making attempts to alleviate their hosts' rural backwardness, but the questions are: how far?, how well have they gone? What are the people's views about these efforts? . It is obvious, answers to the basic questions raised by Dudley are yet to be found and provided in these communities. This study intends to empirically determine the effort of the companies so far to reach the people as perceived by the host communities.

The clamour and campaigns for sustainable rural development in Nigeria are on the increase daily. Equally, there are identifiable strides and efforts by donor agencies (eg World Bank, WHO, UNICEF), governments at all levels (local state and Federal), the people themselves (via self-helps, age grades, CBOs, associations/Clubs) and of course, NGOs e.g. oil companies like Shell, Elf, Agip etc) to alleviate rural poverty and backwardness through a number of development projects/programs.

However, what tends to impede all these noble moves are the never-ending oil exploration activities which, for over forty years, have left trails of environmental degradations and socio-economic deprivations. The questions are: what efforts are the oil companies putting in to improve rural life? How far are such efforts solving the problems on the ground? How satisfied are the rural beneficiaries with the companies' efforts and programs to reach them? It is the intention 
of this study to empirically establish the efforts of oil companies to reach rural dwellers as perceived by respondents.

\section{METHODOLOGY}

Data for this study were collected with a likert-type questionnaire (with responses ranging from strongly agree to strongly disagree). The instrument was collated and sorted into three (3) main categories representing agreement, undecided and disagreement and analyzed based on simple percentages. An item-by-item approach was adopted to analyze the data collected and responses with higher percentage values (of agreement, undecided disagreement) were taken as sample's perception of oil companies' efforts in the study area (see Table 1). Findings were discussed and conclusions drawn based on this

\section{FINDINGS AND DISCUSSIONS}

Findings indicated that a total of $50.8 \%$ of the respondents were between $31-40$ years old, $32.5 \%$ above 40 years, while $13.3 \%$ were between 25-30years. Findings also showed that holders of NCE/Diploma were $50 \%$ of the respondents while $10.8 \%$ were holders of TCII and $13.3 \%$ FSLC holders. From this data, it is apparent that majority of the respondents are quite literate and fully aware of the impact of oil production activities. Thus, their perceptions towards oil exploration effects and companies' development efforts to reach the people would not be borne out of illiteracy (ignorance). It follows that the people exhibit genuine awareness of such adverse effects and appreciation of 'what was', 'what is' and 'what ought to be' as far as their lives and environments are concerned. 
Table 1: Development Efforts of Oil Companies as Perceived by Respondents.

\begin{tabular}{l|l|l|l}
\hline Items & Agree & Undecided & Disagree \\
\hline $\begin{array}{l}\text { There is complete absence of potable water, } \\
\text { electricity, road networks, health and market } \\
\text { centres inspite of company's presence }\end{array}$ & $60 *(50)$ & $6(5)$ & $54(45)$ \\
\hline $\begin{array}{l}\text { Compensations are not normally paid for } \\
\text { property destroyed/damaged by companies }\end{array}$ & & & \\
\hline $\begin{array}{l}\text { Many of your Youths have ready and gainful job } \\
\text { opportunities with the companies. }\end{array}$ & $21(17.5)$ & $2(1.6)$ & $35(29.2)$ \\
\hline $\begin{array}{l}\text { The development of your community is of } \\
\text { primary concern rather than direct monetary } \\
\text { compensations by companies }\end{array}$ & $102(85)$ & $9(7.5)$ & $9(7.5)$ \\
\hline $\begin{array}{l}\text { Oil companies' presence is felt by your people in } \\
\text { terms of available road network and other social } \\
\text { amenities }\end{array}$ & & & \\
\hline $\begin{array}{l}\text { A large population of your youths benefit from } \\
\text { the companies' scholarship schemes }\end{array}$ & $45(37.5)$ & $16(13.3)$ & $59(49.2)$ \\
\hline $\begin{array}{l}\text { Your community is blessed with atleast one or } \\
\text { two of these socio-economic infrastructures: } \\
\text { school building/equipment, market development, } \\
\text { heath centre, water project, road and agriculture } \\
\text { related projects from the companies }\end{array}$ & $75(62.5)$ & $3(2.5)$ & $42(35)$ \\
\hline $\begin{array}{l}\text { Oil companies on the average, have not brought } \\
\text { any development to your community rather than } \\
\text { problems }\end{array}$ & & & \\
\hline $\begin{array}{l}\text { Your community is highly satisfied with the } \\
\text { companies, projects and services to you }\end{array}$ & $58(48.3)$ & $10(8.3)$ & $52(43.3)$ \\
\hline
\end{tabular}

$N=120$; values in parentheses are percentages.

- Source: field survey 1996 and 2000. 
The problems of oil producing rural communities of Rivers State and indeed, Nigeria as a whole are numerous, diverse and varied; rural poverty unemployment and general backwardness are common denominators for them. Their very existence is no doubt threatened by oil activities.

The oil companies, however, have been making a lot of efforts towards lessening the effect of oil exploration activities in these areas. These efforts, although well appreciated by the people are perceived to be inadequate and ill-distributed hence cannot meet the expectations of the entire inhabitants/victims in all the communities. This is confirmed by the small marginal difference between the responses of those who agreed $(50 \%)$ and disagreed $(45 \%)$ with the question of complete absence of potable water and other infrastructural facilities inspite of company's presence; (only $5 \%$ of the respondents were undecided).

Findings also indicated that from a checklist of socio-economic infrastructures such as school building/equipment, market development, health centre, water project, roads/agricultural projects etc a total of $62 \%$ and $35 \%$ agreed and disagreed respectively, that they are blessed with at least one or two, only $2.5 \%$ were undecided. This is an indication that oil companies have made some contributions although on the average, an overwhelming $90.8 \%$ of the respondents maintained that their communities are not highly satisfied with the companies' projects and services to them.

This absence of satisfaction is not only associated with the inadequacy of such projects/efforts but rather that most of the projects agreed for implementation are either abandoned or poorly executed by company's contractors, hence subjecting the people to a state of continual neglect. Indeed, as OMPADEC (1993) observed, there is a 
general absence of basic necessities and rural infrastructure such as good roads, clean water (but polluted rivers, rivulets, and streams), electricity, educational and communication services in many rural areas of Nigeria: these people live in vain and abject poverty.

On the issue of compensations, findings revealed, according to respondents (60.8\%agreed, $25 \%$ disagreed and $14.2 \%$ undecided) that compensations are not normally paid for property destroyed/damaged or at best, not adequate. This confirms Nwidu (1991) who noted with regret that oil companies are insensitive as they never cared when they destroy fishponds, hectares of cropped lands, and trees while exploring. However, whether or not compensations are paid at all or inadequate, they are not the primary issue as the development of the community is of greater importance, noted $85 \%$ of the respondents. To them, compensations are not often seen, it is the physical presence in terms of available socio-economic amenities that matter which $49.2 \%$ as against $37.5 \%$ of the respondents said was not felt at all. This assertion is an indication that these projects are not evenly distributed.

Furthermore, this category of respondents see compensations as something that create bad-blood, unhealthy rivalry, negative power tussle, search for selfish and undue recognition leading to local politicking, petition writings and sell-outs. It is therefore possible that such compensations are paid but some selfish community leaders would divert or embezzle them just to give the companies' bad publicity or image.

Findings further indicated that the communities feel the efforts of the companies are nothing to go by, whereas after they have been displaced from their basic occupations, nothing have been done to provide alternative job opportunities for them as highlighted by $80.8 \%$ of 
the respondents. This finding is consistent with Odu (1994) and Owerre (1990) who noted that the level of youths' unemployment is quite high with its associated senses of frustration. Similarly, another important area of development would have been the education of the people but badly enough, the company's scholarship scheme do not cover a large population of the youths as maintained by $78.3 \%$ of the respondents. Beside this, such scholarship schemes are often directed at so called landlords or land-owing families. "This is a sad situation or development whereas, the problem of rural poverty and environmental devastation caused by oil exploration, do not select victims, but affect all of us equally," lamented one community leader.

\section{CONCLUSION AND RECOMMENDATION}

No meaningful development has taken place in all oil producing communities that participated in the study because, their resources (land, soil, water/aquatic lives, crops, animals, air etc) are far from being preserved and protected from environmental pollution and degradation. There is also the stark absence of basic socio-economic infrastructure hence, collective rural poverty and backwardness even as youth unemployment is still very high.

Accordingly, respondents perceive that the efforts of oil companies so far seen are not only inadequate but ill-distributed. Based on these findings, the following were recommended:

More efforts should be made by the oil companies to improve the level and availability of socio-economic infrastructure and spread across the various communities. 
There is need to involve the host communities fully in the identification, prioritization of their real/felt needs and also planning and implementation of development projects targeted at them.

There is also need to spread the scholarship schemes to go beyond the present "land-lord-beneficiary-strategy" adopted since the effects of oil exploration are experienced by all community members and not only landlords.

Companies' assisted -skills-acquisition programs so far organized for the youths of the communities should be expanded and opportunities increased to cover a large segment of the unemployed youths.

\section{REFERENCES}

Adefolalu, A.A. (1977) The significance of Transportation in Rural Development" In Environmental and Partial Factors in Rural Development in Nigeria: Proceedings of the $20^{\text {th }}$ Annual Conference of the Nigerian Geographical Association (eds) Adejuyigbe, ). and Helleiner, F.M. University of Ife, lle Ife. Pp. 171-175.

Dudley, Seers (1969) "The Meaning of Development" In: Meiers (ed), Leading Issues in Economic Development. Oxford University Press (1984), .95 .

Ibe, K.M. and Umesiobi (1988) "Environmental Sanitation and the Hazards of Ground Water Pollution in Owerri: A case study of Nworie and Otamiri Rivers" In: Critical Issues in Rural Development (ed) Igbozurike, U.M. Owerri, Kartopress. Pp 298-300.

Igbozurike, U.M. (1977)" Self-Help in he context of strategies for Rural Change and Development" in: Environmental and Spatial factors in Rural Development in Nigeria, Proceedings of $20^{\text {th }}$ Annual Conference of the Nigerian Geographical Association (eds) Adejuyigbe and Helleiner 
Ltd.

Loffa, K. (1990) Oil and Nigeria, Akure: Olaniyan Pub. Company, Nig

Nwakasi, E.l. (1991) "The Role of Water Agencies in Rural Development In: Corporate Role in Rural Development (eds) Igbozurike, U.M. Okpara, E.E., ljoma, M.A Owerri Karto Press, (Nig) PP. 114-119

Nwidu, T. (1991)" Oil Boom Era Revisited" In. The Nigerian Tide October 10th

Odu, A.A. (1994) "Oil Companies and Ogbaland: How Far After 20 years". A lecture delivered at Ogba Day Celebration, Rivers State University of Science and Technology, Port Harcourt, Nigeria (Unpublished)

OMPADEC Quarterly Report: Vol. 1 No.1 and 2, 1993/1994,

Oroh, A (1991) "Minorities-Hostage to Nigerian Federation" In: African Guardian September, $23^{\text {rd }}$.

Owere T.M. (1990) ${ }^{n}$ Impact of Petroleum Industries in Ogba/Egbema Districts" A Seminar Paper presented at the University of Port Harcourt, Port Harcourt, Nigeria (Unpublished)

Tolofari, P. (1982), Management Problems of Rapid Urbanization in Nigeria: Ille-lfe: University of Ife Press.

Ukpongson M.A. (1996)" Attitudes of Rural Households Rural towards Oil Exploration in Selected Rural Oil Producing Communities and oil companies in Rivers State" Unpublished M.Sc Thesis of Post Graduate School Federal University of Technology, Owerri, Nigeria .

Ukpongson M.A. \& Onu, D.O (1998) "Attitudes of Rural Households towards Oil Exploration: Implications for Oil Company's Community Development Project in River State" Journal of Technology and Education in Nigeria 3 (1 and 2) 34-41 